\title{
EFEK PENGGUNAAN PROBIOTIK LACTOBACILLUS CASEI DAN BIFIDOBACTERIUM SP TERHADAP ANGKA KONVERSI PAKAN DAN KONSUMSI PAKAN PADA AYAM PETELUR YANG DIINFEKSI ESCHERICHIA COLI
}

\author{
${ }^{1}$ Nabil Fariz Noorrahman, ${ }^{2}$ Widya Paramita Lokapirnasari, ${ }^{3}$ Mohammad Anam Al \\ Arif, ${ }^{4}$ Koesnoto Soepranianondo, ${ }^{5}$ Sri Hidanah, ${ }^{6}$ Sarmanu \\ 1,2,3,4,5,6 Fakultas Kedokteran Hewan, Sekolah Pascasarjana Universitas Airlangga \\ Email: ${ }^{1}$ rahman_nabil@yahoo.co.id, ${ }^{2}$ widyaparamitalokapirnasari@gmail.com, \\ ${ }^{3}$ anamarif@gmail.com, ${ }^{4}$ koesnoto@gmail.com, ${ }^{5}$ srihidanah@gmail.com, \\ ${ }^{6}$ sarmanu@gmail.com
}

\begin{tabular}{l}
\hline Tersedia Online di \\
\hline http://www.jurnal.unublitar.ac.id/ \\
index.php/briliant \\
\hline Sejarah Artikel \\
\hline Diterima pada 19 April 2019 \\
Disetuji pada 29 April 2019 \\
Dipublikasikan pada 22 Mei 2019 \\
Hal. 167-173 \\
\hline Kata Kunci: \\
\hline Pakan Basal, Escherichia Coli, \\
Probiotik, Interaksi \\
DOI: \\
\hline http://dx.doi.org/10.28926/briliant \\
.v3i4.288
\end{tabular}

\begin{abstract}
Abstrak: Penelitian ini bertujuan mengetahui probiotik Lactobacillus casei dan Bifidobacterium sp terhadap rasio konversi pakan dan konsumsi pakan pada ayam petelur yang diinfeksi escherichia coli. Dalam penelitian ini menggunakan sebanyak 120 ekor ayam petelur umur 25 minggu dengan menggunakan metode percobaan desain Rancangan Acak Lengkap (RAL) pola faktorial. Probiotik L.casei $10^{8} \mathrm{CFU} / \mathrm{ml}$ dan Bifidobacterium sp $10^{8}$ $\mathrm{CFU} / \mathrm{ml}$ diberikan seacara oral melalui air minum sebanyak $250 \mathrm{ml}$ air/ekor/hari. Hasil penelitian efek probiotik Lactobacillus casei dan Bifidobacterium ( $\mathrm{p}<0,05$ ) konsumsi pakan tidak menunjukkan perbedaan yang nyata $(\mathrm{p}>0,05)$. Konsumsi pakan tidak menunjukkan perbedaan antara perlakuan dan kontrol yaitu berkisar 113,72 sampai 114,22 g/ekor/hari. Konversi pakan menunjukkan perbedaan yang nyata $\mathrm{p}<0,05$ terhadap FCR. Terdapat interaksi antara infeksi dengan feed additive $\mathrm{p}<0,05$ terhadap FCR.
\end{abstract}

\section{PENDAHULUAN}

Keberhasilan suatu usaha peternakan ayam petelur ditentukan dari pakan (feed), bibit (breed), dan manajemen. Pakan merupakan faktor penentu keberhasilan dalam peternakan untuk menentukan konsumsi, bobot badan dan hasil produk. Permasalahan peternakan ayam petelur yaitu ketergantungan terhadap pemakaian antibiotika. Pada usaha peternakan ayam petelur, pakan memerlukan biaya tertinggi dari seluruh total biaya. Cara yang digunakan peternak yakni meningkatkan efisiensi penggunaan pakan (feed convertio ratio/ FCR) antara lain dengan menambahkan berbagai tambahan pakan seperti enzim dan antibiotika (Manafi et al., 2017). Diperkirakan penekanan populasi mikroba patogen dalam usus merupakan salah satu cara Antibiotic Growth Promoter (AGP) dalam memacu pertumbuhan atau produksi (Kompiang, 2009).

Penggunaaan probiotik sebagai pengganti antibiotik mulai digunakan peternak ayam karena dampak buruk dari residu antibiotik yang dihasilkan (Amer And Khan, 2012). Probiotik bekerja dengan memperbaiki keseimbangan mikroflora didalam usus dan meningkatkan jumlah mikroba yang 
menguntungkan. Probiotik dari genus Lactobacillus dan Bifidobacterium seringkali digunakan didalam peternakan ayam (Rofiq dkk., 2014).

L.casei mampu menghambat berbagai jenis bakteri patogen seperti Salmonela, Vibrio, Listeria, Shigella, Staphylococcus, dan E.coli (Sunaryanto dkk., 2014). Sejumlah Lactobacillus mampu menghasilkan komponen antimikroba yang disebut bakteriosin misalnya asidolin, asidofilin, laktosidin. Pada penelitian sebelumnya, penambahan probiotik L.casei dan L. rhamnosus mampu meningkatkan konsumsi pakan pada ayam pedaging dikarenakan keberadaan probiotik dalam pakan dapat meningkatkan aktivitas enzimatis dan membantu pencernaan, sehingga efisiensi pemanfaatan pakan akan meningkat dan dapat meningkatkan kecernaan pakan (Lokapirnasari dkk., 2016).

Bifidobacterium adalah bakteri yang mampu menghasilkan asam asetat, format, laktat dari fermentasi gula. Asam asetat yang dihasilkan yang dihasilkan memiliki aktivitas daya hambat terhadap bakteri Gram negatif (Rios-covian et al., 2013). Pada penelitian sebelum nya penambahan Bifidobacterium sp pada pakan ayam pedaging mampu menekan pertumbuhan dari E.coli dan bakteri patogen lainnya sehingga meningkatkan konsumsi pakan dan memacu pertumbuhan bobot badan ( Kompiang, 2009).

Escherichia coli patogen merupakan penyebab penyakit kolibasilosis. Kolibasilosis merupakan penyebab kerugian terbesar dalam usaha perunggasan di seluruh dunia karena infeksi yang ditimbulkan. Infeksi dapat menyebabkan gangguan pertumbuhan, penurunan produksi, peningkatan jumlah ayam yang diafkir, penurunan kualitas karkas, dan turunnya produksi telur (Matin et al., 2017). Penyakit yang disebabkan Escherichia coli umumnya memperlihatkan tanda-tanda klinis: kurus, bulu kusam, nafsu makan menurun dan murung. Pertumbuhan ayam terganggu, diare, bulu kotor, dan produksi telur menurun (Suryani dkk,. 2014). Penelitian tentang penggunaan kombinasi L. casei dan Bifidobacterium $s p$ belum pernah dilakukan, sehingga perlu dilakukan penelitian untuk mengetahui efek probiotik $L$. casei dan Bifidobacterium $s p$ terhadap konsumsi pakan dan rasio konversi pakan (FCR) pada ayam petelur yang diiinfeksi Escherichia coli.

Penelitian ini bertujuan untuk mengetahui pengaruh pemberian feed additive yang terdiri dari probiotik L.casei dan Bifidobacterium sp serta AGP terhadap angka konversi pakan dan konsumsi pakan ayam petelur yang diinfeksi Escherichia coli.

\section{METODE}

\section{Waktu dan Tempat}

Penelitian ini akan dilaksanakan pada bulan Oktober 2018 di peternakan ayam petelur milik Bapak Rifky di desa Talun Kecamatan Montong Kabupaten Tuban selama 6 minggu. Analisis pakan dilakukan di Laboratorium Pakan Ternak Fakultas Kedokteran Hewan Universitas Airlangga dan perbanyakan bakteri E.coli di Laboratorium Bakteriologi dan Mikologi Departemen Mikrobiologi Fakultas Kedokteran Hewan Universitas Airlangga.

\section{Materi Penelitian}

Penelitian ini menggunakan 120 ekor ayam petelur umur 25 minggu diperoleh dari peternakan Bapak Rifky di Desa Talun Kecamatan Montong 
Tuban. Pengambilan sampel dilakukan setiap hari untuk penghitungan konsumsi pakan dan FCR.

\section{Metode Penelitian}

Penelitian ini menggunakan metode percobaan dengan menggunakan desain Rancangan Acak Lengkap (RAL) pola faktorial dimana menggunakan 6 perlakuan 4 ulangan dan setiap ulangan berisikan 5 ekor ayam petelur, sesuai dengan tabel 1 .

Tabel 1. Pola Faktorial Penentuan Kelompok Perlakuan

\begin{tabular}{|c|l|l|l|l|}
\hline & $\begin{array}{c}\text { Eschericihia } \\
\text { coli }\end{array}$ & \multicolumn{3}{|c|}{ Faktor 2 (b) } \\
\hline \multirow{4}{*}{$\begin{array}{c}\text { Faktor } \\
1(a)\end{array}$} & & Kontrol (b0) & $\begin{array}{l}\text { Antibiotika } \\
\text { 0,1\% (b1) }\end{array}$ & $\begin{array}{l}\text { Probiotik L. casei 0,5\% } \\
\text { dan Bifidobcterium sp. } \\
0,5 \% \text { (b2) }\end{array}$ \\
\cline { 2 - 6 } & Tidak (a0) & a0b0 & a0b1 & a0b2 \\
\cline { 2 - 6 } & Infeksi (a1) & a1b0 & a1b1 & a1b2 \\
\hline
\end{tabular}

Keterangan:

a0b0 : Pakan jadi tanpa probiotik dalam air minum tanpa infeksi E. coli

a0b1 : Pakan jadi ditambah AGP $0,1 \%$ dicampurkan ke dalam pakan ayam tanpa infeksi E. coli

a0b2 : Probiotik 0,5\% Lactobacillus casei $+0,5 \%$ Bifidobacterium yang dicampurkan ke dalam air minum tanpa infeksi $E$. coli

a1b0 : Pakan jadi tanpa probiotik dalam air minum dengan infeksi $E$. coli

a1b1 : Pakan jadi ditambah AGP $0,1 \%$ dicampurkan ke dalam pakan ayam dengan infeksi $E$. coli

a1b2 : probiotik 0,5\% Lactobacillus casei $+0,5 \%$ Bifidobacterium yang dicampurkan ke dalam air minum dengan infeksi $E$. coli

Pemberian antibiotik dicampurkan kedalam pakan komersil sebanyak 0,1\%, dimulai dari awal masa adaptasi ayam selama 7 hari berturut-turut. Probiotik L.casei $10^{8} \mathrm{CFU} / \mathrm{ml}$ dan Bifidobacterium $\mathrm{sp} 10^{8} \mathrm{CFU} / \mathrm{ml}$ diberikan seacara oral melalui air minum sebanyak $250 \mathrm{ml}$ air/ekor/hari. Pemberian probiotik dimulai dari hari pertama sampai hari terakhir perlakuan yakni selama 4 minggu (dari umur ayam 25 minggu sampai $30 \mathrm{minggu}$ ). Bakteri E. coli $10^{8} \mathrm{CFU} / \mathrm{ml}$ diinfeksi kan secara oral di hari ke 21 (umur ayam 28 minggu).

\section{Variabel Pengamatan}

Variabel yang diamati pada penelitian ini meliputi konsumsi pakan dan rasio konversi pakan. Konsumsi ransum adalah faktor yang menentukan kehidupan produksi pada ayam. Faktor-faktor yang mempengaruhi konsumsi pakan antara lain, keadaan fisiologi ternak, fisiologi lingkungan, palatabilas dan kandungan nutrisi ransum. Konsumsi ayam petelur periode layer adalah 110$120 \mathrm{~g} / \mathrm{ekor} / \mathrm{hari}$. Penghitungan konsumsi pakan adalah dengan cara pakan yang diberikan dikurangi pakan sisa setelah pemberian (Ketaren, 2010).

Konversi pakan merupakan rasio antara jumlah pakan yang dikonsumsi dengan berat telur yang dihasilkan. Semakin tinggi FCR maka semakin buruk, artinya penggunaan pakan tersebut kurang ekonomis sebaliknya, Semakin kecil jumlah pakan yang dibutuhkan untuk menghasilkan produk baik berupa pertambahan bobot badan ayam maupun telur, berarti semakin efidien pemberian pakan tersebut (Lokapirnasari, 2016). 


\section{Analisis data}

Data yang diperoleh menggunakan Rancangan Acak Lengkap (RAL) pola faktorial, diolah dengan dianalisis statistik Analysis of Variance (ANOVA) untuk mengetahui apakah terdapat perbedaan yang nyata pada perlakuan yang diberikan. Selanjutnya, apabila diperoleh hasil yang berbeda nyata $(\mathrm{P}<0,05)$, dilanjutkan dengan Uji Jarak Berganda Duncan (Kusriningrum, 2008).

\section{HASIL}

\section{Konsumsi Pakan}

Hasil penelitian terhadap konsumsi pakan dapat dilihat pada Tabel 2.

Tabel 2. Rerata dan Simpangan Baku Konsumsi Pakan Pada Ayam yang Diinfeksi E.coli dan ditambah Probiotik L.casei dan Bifidobacterium. (gram/ekor/hari).

\begin{tabular}{c|ccc|c|}
\hline \multirow{2}{*}{ Faktor a } & \multicolumn{3}{|c|}{ Faktor b } & \\
\cline { 2 - 5 } & Kontrol (b0) & $\begin{array}{c}\text { Antibiotika 0,1 } \\
\text { \% (b1) }\end{array}$ & $\begin{array}{c}\text { Probiotik } \text { L. casei } \\
\text { 0,5\% dan } \\
\text { Bifidobcterium } \\
\mathbf{0 , 5 \%}\end{array}$ & Rata- rata \\
\hline Non infeksi (a0) & $113.90 \pm 0.081$ & $113.92 \pm 0.081$ & $113.97 \pm 0.60$ & $113.93 \pm 0,36$ \\
Infeksi (a1) & $113.90 \pm 0.081$ & $113.72 \pm 0.081$ & $114.22 \pm 0.69$ & $113.94 \pm 0,28$ \\
\hline Rata-rata & $113,90 \pm 0.081$ & $113,82 \pm 0.081$ & $114.09 \pm 0,64$ & \\
\hline
\end{tabular}

\section{Feed Convertion Ratio (FCR)}

Hasil penelitian terhadap feed convertion ratio dapat dilihat pada Tabel 3.

Tabel 3 Rerata dan Simpangan Baku feed convertio ratio Pada Ayam yang Diinfeksi E.coli dan ditambah Probiotik L.casei dan Bifidobacterium. (gram/ekor/hari).

\begin{tabular}{|c|c|c|c|c|}
\hline \multirow{2}{*}{ Faktor a } & \multicolumn{3}{|c|}{ Faktor b } & \multirow[b]{2}{*}{ Rata-rata } \\
\hline & $\begin{array}{c}\text { Kontrol } \\
\text { (b0) }\end{array}$ & $\begin{array}{l}\text { Antibiotika } \\
0,1 \% \text { (b1) }\end{array}$ & $\begin{array}{l}\text { Probiotik } L \text {. casei } 0,5 \% \text { dan } \\
\text { Bifidobcterium sp } 0,5 \% \text { (b2) }\end{array}$ & \\
\hline Non infeksi (a0) & $2.30^{\mathrm{c}} \pm 0.08$ & $\begin{array}{l}2.07^{\mathrm{b}} \pm \\
0.08165\end{array}$ & $1.95^{\mathrm{a}} \pm 0.05$ & \multirow{3}{*}{$\begin{array}{l}2.11^{\mathrm{a}} \pm 0.07 \\
2.25^{\mathrm{b}} \pm 0.07\end{array}$} \\
\hline Infeksi (a1) & $2.40^{\mathrm{c}} \pm 0.08$ & $2.40^{\mathrm{c}} \pm 0.08$ & $1.95^{\mathrm{a}} \pm 0.05$ & \\
\hline Rata - rata & $2.35^{\mathrm{c}} \pm 0.08$ & $2.20^{\mathrm{b}} \pm 0.08$ & $1.95^{\mathrm{a}} \pm 0.05$ & \\
\hline
\end{tabular}

Keterangan: ${ }^{\mathrm{a}, \mathrm{b}, \mathrm{c}}$ Superskrip yang berbeda menunjukkan adanya perbedaan yang nyata $(\mathrm{p}<0,05)$

PEMBAHASAN

Konsumsi Pakan

170 BRILIANT: Jurnal Riset dan Konseptual Volume 4 Nomor 2, Mei 2019 
Berdasarkan hasil penelitian dengan menggunakan uji Analysis of Variance (ANOVA) menunjukkan bahwa faktor infeksi tidak ada perbedaan yang nyata $(\mathrm{p}>0,05)$ terhadap konsumsi pakan. Pemberian feed additive pada konsumsi pakan juga tidak menunjukkan perbedaan yang nyata $(\mathrm{p}>0,05)$, sehingga interaksi infeksi dengan feed additive tidak menunjukkan hasil yang berbeda nyata $(\mathrm{p}>0,05)$. Konsumsi pakan tidak menunjukkan perbedaan antara perlakuan dan kontrol yaitu berkisar 113,72 sampai 114,22 g/ekor/hari.

Pemberian probiotik yang diinfeksi E.coli memiliki nilai tertinggi pada konsumsi pakan sebesar 114,22 g. Hal ini sesuai dengan pendapat (ISA, 2015) bahwa standart konsumsi pakan ayam petelur strain Isa brown umur 25-32 minggu sebesar $114 \mathrm{~g}$, sedangkan perlakuan terendah terdapat pada perlakuan ayam petelur infeksi E.coli yang diberikan antibiotika (AGP) yaitu sebesar 113,72. Faktor yang menyebabkan tingi rendahnya konsumsi pakan saat penelitian adalah kondisi ayam,kondisi kandang, cuaca, lama penyinaran di malam hari, dan kualitas pakan (Lordelo et al, 2016). Faktor yang mempengaruhi konsumsi pakan adalah umur, palatabilitas pakan, energi pakan, tingkat produksi, kuantitas pakan, kualitas pakan. Serat kasar, kerapatan jenis atau kepadatan pakan, lemak kasar (Allama dkk., 2012). Faktor yang menyebabkan konsumsi pakan rendah pada penelitian adalah sudah tercukupinya kebutuhan nutrisi dan energi di dalam tubuh ayam. Konsumsi pakan yang rendah disebabkan karena nutrisi yang dibutuhkan ayam petelur untuk kelangsungan hidup baik untuk berproduksi maupun bereproduksi sudah tercukupi (Natalia dkk., 2016).

\section{Feed Convertion Ratio (FCR)}

Berdasarkan hasil analisis anova menunjukkan bahwa faktor infeksi dan pemberian feed additive menunjukkan perbedaan yang nyata $\mathrm{p}<0,05$ terhadap FCR. Terdapat interaksi antara infeksi dengan feed additive $\mathrm{p}<0,05$ terhadap FCR. Hasil uji lanjutan dengan uji Duncan menunjukkan bahwa perlakuan a0b0 dengan a1b0 berbeda nyata, a0b1 dengan a1b1 berbeda nyata dan a0b2 dengan a1b2 tidak berbeda nyata. Hasil Feed Conversion Ratio tertinggi diperoleh pada perlakuan alb0, alb1 sebesar 2,40 dan a0b0 sebesar 2,30, sedangkan hasil terendah terdapat pada perlakuan a0b1 sebesar 2,07, a0b2 dan a1b2 sebesar 1,95.

Konversi pakan saat penelitian dihitung dengan cara membagikan pakan yang dikonsumsi dengan berat telur yang dihasilkan (Cesari et al, 2014). Semakin tinggi FCR maka semakin buruk, artinya penggunaan pakan tersebut kurang ekonomis sebaliknya, semakin kecil jumlah pakan yang dibutuhkan untuk menghasilkan produk baik berupa pertambahan bobot badan ayam maupun telur, berarti semakin efisien pemberian pakan tersebut(Lacin et al, 2008). Faktor yang mempengaruhi konversi pakan antara lain: bentuk fisik pakan, berat badan ayam, lingkungan pemeliharaan, stress, jenis kelamin (lokapirnasari dkk.,2011).

\section{KESIMPULAN}

1. Penambahan feed additive $(0,5 \%$ Lactobacillus casei $+0,5 \%$ Bifidobacterium) melalui air minum pada ayam yang diinfeksi E.coli tidak mempengaruhi konsumsi pakan ayam petelur.

2. Penambahan feed additive $(0,5 \%$ Lactobacillus casei $+0,5 \%$ Bifidobacterium) dapat menurunkan angka Feed Convertion Ratio (FCR) sebesar 1,95 pada ayam petelur yang diinfeksi E.coli. 


\section{SARAN}

Diharapkan untuk peternak menambahkan probiotik L. casei dan Bifidobacterium $s p$ untuk mendapakan hasil produksi yang maksimal dan untuk peneliti diharapkan ada penelitian mengenai daya nafsu makan ayam petelur dengan menghitung waktunya ketika ayam diberi pakan.

\section{DAFTAR RUJUKAN}

Allama, H., Sofjan, O., Widodo, E, dan Prayogi, H, S., 2012. Pengaruh Penggunaan Tepung Ulat Kandang (Alphitobius Diaperius) Dalam Pakan Terhadap Penampilan Produksi Ayam Pedaging. Jurnal Ilmu-Ilmu Peternakan. 22(3): 1-8.

Amer, M, Y, and Khan S, H., (2012). A Comparison between the Effects of A Probiotic and An Antibiotic on the Performance of Desi Chickens. Veterinary World, 5(3): 160-165.

Cesari, V., Mangiagialli, M.G., Giardini, A., Galimberti, B., Carter, S., Gallazzi, D., and Toschi, I., 2014. Egg Quality And Productive Performance Of Laying Hens Fed Different Levels Of Skimmed Milk Powder Added To A Diet Containing Lactobacillus Acidophilus. Poultry Science 93: 1197-1201.

ISA, 2015. Nutrition Managemen Guide. A Hendrix Genetics Company. Netherlands.

Ketaren, P, P, 2010. Kebutuhan Gizi Ternak Unggas di Indonesia. Wartazoa 20(4).

Kompiang, I, P, 2009. Pemanfaatan Mikroorganisme Sebagai Probiotik Untuk Meningkatkan Produksi Ternak Unggas di Indonesia. Pengembangan Inovasi Pertanian 2:177-1991.

Kusriningrum, R, S, 2008. Buku Ajar Perancangan Percobaan, Fakultas kedokteran Hewan Universitas Airlangga. Surabaya.

Lacin, E., A. Yildiz, N. Esenbuga, and M. Macit .2008. Effect of differences in the initial body weight of groups on laying performance and egg quality parameters of Lohmann laying hens. Czech. J. Anim. Sci. 53(11):466-471.

Landman, W, J,and van Eck, J, H., 2015.The incidence and economic impact of the Escherichia coli peritonitis syndrome in Dutch poultry farming. Avian Pathol: 9457:1-27.

Lokapirnasari, W, P., Rahmawati A., dan Elliyani H., 2016. Potensi Penambahan Bakteri Asam Laktat Lactobacillus casei dan Lactobacillus rhamnosus Terhadap Konsumsi Pakan dan Konversi Pakan Ayam Pedaging. J Agro Vet 5:43-49 
Lokapirnasari, W, P., Soewarno., dan Damayanti, Y., 2011. Potensi Crude Spirulina Terhadap Protein Effisiensi Rasio Pada Ayam Petelur. Jurnal Ilmiah Kedokterna Hewan. 2(1): 5-8.

Lordelo, M., Fernandes, E., Bessa, R, J, B., and Alves, S, P., 2016. Quality Of Eggs From Different Laying Hen Production Systems, From Indigenous Breeds And Specialty Eggs. Poultry Science 96:1485-1491.

Manafi, M., Khalaji, S., Hedayati, M., and Pirany., N., 2017 Efficacy Of Bacillus Subtilis And Bacitracin Methylene Disalicylate On Growth Performance, Digestibility, Blood Metabolites, Immunity, And Intestinal Microbiota After Intramuscular Inoculation With Escherichia Coli In Broilers. Poultry Science, 96, 1174-1183.

Matin, M, A., Islam, M. A., And Khatun, M, M., 2017. Prevalence Of Colibacillosis In Chickens In Greater Mymensingh District Of Bangladesh. Veterinary World 10: (1-29).

Natalia, D., Suprijatna, E,. dan Muryani, R, 2016. Pengaruh penggunaan limbah industry jamu dan bakteri asam laktat (lactobacillus sp.) sebagai sinbiotik untuk aditif pakan terhadap Performans ayam petelur fase layer. Jurnal Ilmu-Ilmu Peternakan 26 (3):6-13.

Rios-Covian, D., Arboleya, S., and Hernandez-Barranco, A, M., 2013. Interactions between bifidobacterium and bacteroides species in cofermentations are affected by carbon sources, including exopolysaccharides produced by bifidobacteria. Appl Environ Microbiol; 79:7518-7524

Rofiq, S., Martius, E., dan Marwoto, B., 2014. Uji Kemampuan Lactobacillus Casei Sebagai Agensia Probiotik. Balai Pengkajian Teknologi Banten. JBBI 1(1): 9-15.

Sunaryanto, R., Martius, E., Marwoto, B., 2014. Uji Kemampuan Lactobacillus Casei Sebagai Agensia Probiotik. Jurnal Bioteknologi \& Biosains Indonesia Vol 01 No 01.

Suryani, A, E., Karimy, M, F., Istiqomah, L., Sofyan, A., Herdian, H., dan Wibowo, M, H., 2014. Prevalensi kolibasilosis pada ayam broiler yang diinfeksi escherichia coli dengan pemberian bioaditif, probiotik dan antibiotik. Laboratorium Mikrobiologi Fakultas Kedokteran Hewan Universitas Gadjah Mada. Bagian Pakan dan Nutrisi Ternak. Vol.17.No.2. 